\title{
Roles of Christian campus fellowships in the fight against cultism in Nigerian universities
}

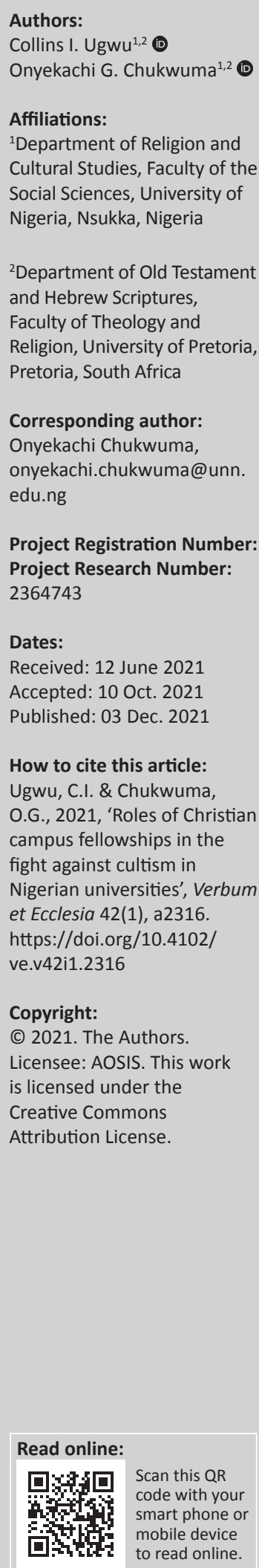

Cultism is prevalent in most tertiary institutions in Africa. There is no gainsay that this vice is generally unacceptable from both socio-cultural and religious viewpoints. Unfortunately, despite the detrimental tendencies associated with it, some students actively engage in it. Hence, various governmental and non-governmental organisations (NGOs) have risen to campaign against cultism in tertiary institutions. The thrust of this research, therefore, is to investigate the roles of Christian campus fellowships in the fight against cultism amongst students of Nigerian universities, with reference to the University of Nigeria, Nsukka (UNN). It also explores the challenges which the activities of cult groups pose to the university community. Utilising the descriptive method of data analysis, this work discovered that Christian campus fellowships are both a significant and a veritable tool in the fight against cultism in the UNN. As part of her primary and social responsibilities, Christian campus fellowships preach and teach against cult activities in tertiary institutions. They also intervene through some philanthropic gestures and other ecclesiastical activities which are primarily geared towards inculcating right values and godly characters in students, encouraging students who are members of cult groups to denounce their membership and also discouraging students from joining cult groups. The data for this research were drawn from both primary (personal communication) and secondary sources (books, journals and internet materials). The major finding of this article reveals that Christian campus fellowships in the UNN, have made remarkable strides in the campaign against the involvement of students in cultism.

Intradisciplinary and/or interdisciplinary implications: The article explicitly lays bare the contributions of Christian campus fellowships in order to bring cult practices to a barest minimum amongst students of the UNN. The study contributes to modern discourses on juvenile delinquency with respect to disciplines such as religion, sociology, social work and psychology.

Keywords: cultism; cultist; secret cult; Christian campus fellowship; University of Nigeria; Nsukka.

\section{Introduction}

Cultism is the practice of activities associated with secret cults. Secret cults are organisations whose memberships and mode of operations are considered to be unconventional and known to members only. Ekwunife (2000) noted that:

[I]t is a systematized form of organisation with a religious overtone in which members are engaged in concerted hidden activities whose overall ends and results spell doom for the members, the community and society at large. (p. 5)

Ogunbameru (2004) reiterated that a secret cult is:

$[A]$ ny form of organisation whose activities are not only exclusively kept away from the knowledge of others but such activities are carried out at odd hours of the day and they often clash with the accepted norms and values of everyday life. (p. 91)

Cultism is a common feature of many Nigerian educational institutions. According to Eneji (1996):

[F]rom the university to the polytechnics, colleges of education and other tertiary institutions and some secondary schools come stories of violence, torture and unwanted intimidation executed by members of secret cults. (p. 19)

Kadiri (2018:1) noted that 'Cultism is one major social vice confronting the Nigerian educational sector. There is hardly any academic session without reported cases of cult activities in many 
Nigerian tertiary institutions'. Similarly, Idoko (2020) asserted that:

[C]ultism is a menace which hampers growth and development in tertiary institutions. The mayhem generated by the activities of cult groups has resulted in loss of lives, property and abrupt closure of some universities. Many students have lost focus and become disorientated due to their involvement in cult activities. Some others have been robbed, physically assaulted, maimed, intimidated and sexually abused such that the society have remained disquieted by the activities of cult groups. (p. 55)

There is no gainsay that as a result of the detrimental tendencies associated with the activities of cult groups, there has assumed a nationwide concern on how to eradicate cultism in Nigerian tertiary institutions. For instance, the Federal Government of Nigeria in an attempt to eradicate this social vice has enacted many laws and policies with the primary aim of charging various school authorities to eradicate cultism in their schools or face the risk of being closed down (Egbochukwu 2009). On the part of the authorities of various universities, public lectures and symposium aimed at sensitising the students and entire university community on the dangers associated with involvement in cultism and its unacceptability by the university authorities have been organised. Likewise, campaigns are carried out by non-governmental organisations (NGOs) through seminars that aim at discouraging students from belonging to cult groups as well as encouraging students who are members to denounce their membership. To this end, the researchers appreciate the efforts of the federal government, educational or social institutions and NGOs in fighting this anomaly but it is glaring that the desired results are yet to be achieved. Okorie (1999) recapitulated that:

$[D]$ espite all efforts to exterminate it, it seems to be waxing stronger and stronger such that membership in secret cults has even extended beyond tertiary institutions and is fast taking roots among secondary school students. Efforts by various organs of the government have failed to curtail the menace of these cults. Also, the school authorities do not relent in their efforts either, yet, the menace continues to infest our educational institutions. (p. 49)

Nwankwo (2020:2) also submitted that new strategies have to be employed in the eradication of cultism amongst Nigerian undergraduates, because the efforts of both governmental and non-governmental bodies have only yielded little results.

It is against this backdrop that this article examines the roles of Christian campus fellowships in the fight against cultism in the University of Nigeria, Nsukka (UNN). The investigation was carried out through personal communication (oral interview) which is one of the primary methods of data collection for descriptively analysed research works. Descriptive analytical methodology, also referred to as the phenomenological method, describes the shared and specific experiences of individuals of a concept or a phenomenon. Creswell (2007) wrote that:

$[P]$ henomenological method is a qualitative research method which seeks to study and describe the lived experience of a group of people within a particular locality. The basic goal of the approach is to arrive at an explicit description of the nature of the particular phenomenon under investigation. (p. 57)

The researchers obtained the informed consent to critically analyse the views of 51 informants (pseudonyms were used) from 24 Christian campus fellowships in the UNN in the article (see Appendix 1). A common view of the informants is that the practices followed by cultists are aberrations of the laws of God. Christian campus fellowships have the core mandate of preaching against $\sin$ in all its ramifications. The teachings, liturgy and other ecclesiastical practices of Christian campus fellowships are all targeted at promoting godliness and Christian values amongst students. Therefore, the major finding of this article indicates that the Christian campus fellowships in the UNN have not left any stone unturned in their campaign against the involvement of students in cult practices. Through their numerous ecclesiastical practices and social action evangelistic approach, this article submits that the menace of cultism has been reduced to the barest minimum in the UNN.

\section{Conceptual clarifications} Cultism

Cultism can be referred to as the practices of any social or religious group whose ideologies are secret and esoteric. Ibenegbu (2018) reiterated that the characteristics of cultism are thus: (1) cultism is a social or spiritual or religious practice, (2) cultism is practised by a group of individuals, (3) cultism changes the values of the individuals who engage in it, and (4) cultism affects the overall life of a community whose members engage in it. By implication, the negative effects of cultism go beyond an individual and extend to a society. In his book, Kalu (2001:38) used the synonym 'secret societies' which he defined as any 'association, group, or body of persons whether registered or not that uses secret signs, oaths, rites as symbols'. Secret cults are formed to promote a cause, to further the interest of its members, and to aid one another under any circumstances without due regard to merit, fair play or justice to the detriment of the legitimate interest of those who are not members. Members are sworn to observe oaths of secrecy and their activities are not known to the public at large. Names and identities of cult members are kept secret and their meetings are also held in secret. The common feature in the above definitions is that cultism is a secret and destructive affair. More so, cult practices are neither known by nor generally acceptable to the public.

\section{Christian campus fellowship}

The term 'fellowship' denotes a meeting of a group of people who share similar ideas and do things together for the common good of its members. It is a meeting of those who share the same religious interests and beliefs. Enemuo (2021) reiterated that it is how people who share the same interest and ideologies come together to worship their god and offer sacrifices to their god or supernatural being. 
A Christian campus fellowship is a formal gathering of students for Christian religious purposes. Some staff of various campuses also belong to Christian campus fellowships in which case, they oversee the activities of the students who are often in the majority. Christian campus fellowships provide students with the opportunity of contemporary Christian worship and support. Christian campus fellowships promote the Christian faith amongst students.

\section{Origin or activities of cultism in Nigerian universities}

There is a consensus amongst many scholars such as Kalu (2001) and Ajayi, Ekundayo and Osalusi (2010) that the origin of cultism in Nigerian universities can be traced to the Sea Dog confraternity (Pyrates), which was founded by Wole Soyinka and six others (Olumuyiwa Awe, Ralph Opara, Tunji Tubi, Aig Imokhuede, Pius Olegbe and Olu Agunloye) at the University of Ibadan (formerly known as University College, Ibadan) in 1952. Ajayi et al. (2010) noted that in the beginning, the operations of this confraternity were peaceful and nonviolent with the primary aims of abolishing conventions, reviving the age of chivalry and to end tribalism and elitism. They sought to speak out against the numerous social ills which were fast gaining firm ground in the university, by promoting positive values and good moral conducts. Kalu (2001:40) restated that 'the objectives of Sea Dog confraternity were to stand against moribund convention, tribalism; and to promote humanistic ideas, comradeship and courteousness among students'. It should also be noted that the members were engaged in humanitarian activities such as donation of blood to hospitals and assisting the needy and less-privileged members of the society (Adejoro 1995).

Kalu (2001) noted that unfortunately, the intention of Wole Soyinka and his six friends failed when new cult groups were formed by either the former members of Sea Dog confraternity who were suspended for their inability to meet up with the standard of the group or those whose request for membership were not granted. Adejoro (1995) lamented that little did Soyinka and his friends realise that they were making history nor did they come to terms with the fact that students and indeed youths radicalism was being given a national boost and the unleashing of a national vanguard. Unlike the first cult group formed by Soyinka, these later cults had mysterious and questionable objectives as their activities became destructive and destabilising to any society. Their activities were filled with weirdness, horror and violence. Odoziobodo (1991:46) asserted that 'They commit unbelievable atrocities on campus. They harass both lecturers and non-members. They perform rituals and in many occasions, students get harmed or die and properties destroyed'. Some of the later cult groups are: Black axe, Black Mamba, Buccaneers, Mafia, Maphites, EIYE confraternity, Vickings, etc.

Although the history of cultism in Nigerian universities dates back to some 50 years, its involvement in violence became manifested only after about three decades (Osondu 2019). The history of cultism in Nigerian tertiary institutions is that of factionalism and of how evil overcomes good intentions. It is the history of how discontented, unscrupulous, selfinterested groups endeavoured to intimidate and control others. Thus, in contemporary times, cultism in Nigerian universities is characterised by malevolent activities that are mind-boggling, irritating and distasteful. They include: intimidation, torture, voodoo ritual practice especially during initiation, robbery, sexual harassment, drug/substance abuse, exam malpractice, coercion of lecturers for marks, advance fee fraud, kidnapping, murder and other anti-social behaviours and vices (Ozoemene 2019). These activities have led to the death of many, both members and non-members. Though the exact death toll of secret cult activities in the University of Nigeria is unclear, according to Okwu (2006), over 5000 students and lecturers have died on Nigerian campuses as a result of cult-related violent clashes. Bodunrin (2002) maintained that cultism is evil, barbaric and runs counter to democratic principles. Cultism leads to violence; and when violence erupts, everybody suffers it, blood is spilled, lives are cut short, limbs are maimed and graduation years are prolonged. Secret cults create an atmosphere of indiscipline, chaos and insecurity of life and property. Other challenges which cult groups pose in tertiary institutions, according to Okorie (1999:46) are 'fear, unrest among students, conscription of members, lack of respect to authorities and disruption of academic work'.

\section{Reasons for students' involvement in cultism}

Undoubtedly, some students who were cultists were either intimidated to join or they were not duly informed about the activities of the group before they joined. Some were deceived to believe that what they were being asked to join was an ordinary social club. However, some cultists became members with full consciousness and conviction. Okorie (1999) posited that:

$[D]$ espite the public outcry and condemnation of the secret cults in our educational institutions, many students still pick interest in belonging to them. Fresh memberships are still recorded while old members still renew their membership and hold tenaciously to the cult's activities. (p. 53)

Similarly, Idoko (2020:47) noted that 'one of the hindrances to education in Nigeria is students' involvement in cultism and other related vices such as examination malpractice, drug abuse and sex abuse'.

Nwankwo (2020:32) submitted that 'one of the reasons which make students join cult groups is negative influences'. Negative influences refer to people or things that teach and encourage others to do wrong. More often than not, these influences come from peers, parents, environment, social media and others. Unfortunately, students become victims to these influences because of ignorance, indiscipline, lack of self-control, fear, greed and desire to be like others. Some students develop an interest in cultism as a result of peer 
group influence and pressure. There is no gainsay that one of the characteristics of youth development is a shift of emphasis on social relationships from parents or guardians to peers. Some students join cult groups because their roommates or classmates are members. Because of their need for continued acceptance, they get associated with secret cults. According to Ufuoma (2007:23) 'Some students joined cult groups based on the assumption that they will be regarded as weaklings or mere boys if they do not join'.

In addition, a student whose parent or parents or guardians are cultists may deem it necessary to toe the line of his or her parents by becoming a member of a secret cult. Children and youths learn more through what they see adults do. Ekwunife (2000:14) added that 'parents who always quarrel with each other are indirectly sowing seeds for cultism for their children'. More so, when there is no cordial relationship between parents and their children, they may tend to join cult groups as a way of enforcing their independence from their parents. Some students who have misunderstandings with their parents have joined secret cults in order to assert their independence from their parents or to square even with them (Okorie 1999). Students who have abusive parents may also resort to joining cult groups as a means of indirect punishment to their parents. Parents who deprive their children of parental love and care may be pushing them to associate with cult groups where they often find affection, consolation and a sense of belonging. Furthermore, the environment and media (social, printed and electronic) are inundated with violent acts such as murder, rape and robbery which are capable of propelling students to join cult groups in order to practise what has been viewed on the media. So, they find cult groups a good option because it encourages violent acts.

According to Idoko (2020:15), 'some students join cult groups because of complex problems'. Most students who are from unstable and poor families often have complex problems. They may decide to join cults because of the perception that cult groups are organisations where they will be readily accepted irrespective of their social status. Similarly, some students join cult groups because of the need for power and protection. They are made to understand that cult groups provide unlimited power and protection over/ against constituted authorities. Their need to be respected and dreaded amongst their fellow students and lecturers lures them to associate with cult practices. Odoziobodo (1991:17) noted that 'many become members because they need academic and social protection. The majority of cult members are students who are not brilliant and are lazy to study'. So, they deem it necessary to join cults so that they can freely cheat in examinations or even intimidate lecturers into passing them.

Some students join cult groups out of ignorance. They are unable to know the difference between acceptable social groups and cult groups. Most of them are made by peers to believe that the cult group is just a social gathering. Out of ignorance and lack of discernment, they associate themselves in cult groups and by the time they discover what they are into, it becomes very difficult to disassociate themselves.

\section{Contributions of Christian campus fellowships in the fight against cultism in the University of Nigeria, Nsukka}

This section examines the contributions which various Christian campus fellowships have made in the campaign against cultism at the UNN. As established in the introduction of this work, the researchers through the medium of semistructured interview elicited information from 51 informants who are members of different 24 Christian campus fellowships in the UNN.

\section{Campaign through expounding the scriptures}

Christian campus fellowships have made frantic efforts to curb cultism in the UNN through the instrument of the word of God. Ezeudu, Igwe and Ugo (informants) submitted that:

'[T]he core divine assignment for all Christian students' groups is to preach against sin and draw young men and women to the kingdom of God by accepting the free gift of salvation.'

Ekwunife (2000) recapitulated that:

[T] he influence of church organizations cannot be minimized in character formation of youths in tertiary institutions. It is the key duties of the church to provide sound moral and ethical education which direct human consciences towards doing good and avoiding evil. (p. 20)

The instruments through which the dictates of God are made known are preaching, teaching, room to room evangelism, Bible studies, hostel morning devotion and morning cry. Although the approaches of these instruments vary, they are all geared towards making students to be at peace with God; they are aimed at promoting godly character and sound values amongst students. Ama and Okolie (informants) reiterated that 'there is no activity carried out by campus fellowships which is not intended to make students become friends and disciples of Jesus Christ'. Even though the activities are carried out in a way in which it will be appealing to students (majority of whom are youths), they are targeted at emphasising the significance of the good news of the birth, death and resurrection of Jesus Christ. In fact, Diugwu (informant) added that 'any message which is not directly/ indirectly aimed at reconciling students to God and emphasizing the truth about the "Second Coming of Jesus" is not a valid message'.

There is no explicit narrative or rhetoric on cultism in the Bible; but the Bible explicitly condemns all the activities which are carried out by cultists. Undoubtedly, all the practices of cult groups such as murder, rape, robbery and other vices are strongly condemned in the Bible, as they are aberrations of the laws of God. Asogwa, Jideofor and Nnam (informants) supported that in the fellowship which they 
belong to, preachers rarely make direct discussions about the menace "cultism" probably because there are no scriptures which directly expounds it'. However, all the ills which are carried out by cultists are preached against with appropriate scriptural supports. Amaechi, Chikwem and Dike (informants) submitted that 'through the instruments of "altar call," many guest preachers have made some students to denounce their cult membership'. Chikwem (informant) narrated that 'on a certain Sunday fellowship, a guest preacher made an altar call for those who desire to denounce their cult membership. To the amazement of all, three students stood up and walked to the altar.' The guest preacher led them through the prayers of confession and repentance, and all surrendered their lives to Christ. The follow-up committee of the fellowship continued to disciple them and presently, one of them is an active minister in one of the Pentecostal churches in Nigeria.

According to Ezeilo and Ogbu (informants), 'in the fellowship they attend, Bible studies are conducted every Thursday. Unlike Sunday gathering, the Bible studies offer opportunities for participants to engage in interactive sessions'. They make use of Bible study manual which is primarily meant for students. The Bible study series are written in a way that it will be understandable and at the same time thought provoking to readers and participants. Room to room evangelism, hostel morning devotion and morning cry are other methods which Christian campus fellowships in the UNN utilise to campaign against cultism. Members of Scripture Union Campus Fellowships (SUCF), Nigerian Federation of Catholic Students (NFCS) and some other fellowships engage in hostel morning devotion whereby all members of the fellowship in a hostel simultaneously gather by 5:00 am to pray and meditate on the word of God (Eme, Ebizie and Nduka: informants). For instance, members who are in Alvan Hall, Balewa Hall and other halls meet at a designated place in their respective halls. In the same vein, Adetunji and Egbuonu (informants) noted that 'members of Word of Life Student Fellowship (WLSF) embark on room to room evangelism every third (3rd) Saturday of the month'. On evangelism days, they meet at designated places and after prayers, they move to students' hostels to preach. They add that in the month of May 2020, they carried out their evangelism at Balewa and Mbanefo Halls. The female members visited Balewa Hall whilst the male members went to Mbanefo Hall. Members of various Christian campus fellowships also preach the word of God in their respective classrooms, most especially when students are waiting for a lecture to commence. Ndukaaku (informant) asserted that 'he utilizes every opportunity to preach to students, especially those who are waiting for a lecturer'. He narrated that on a certain day, they were waiting for a lecturer in George Marion Johnson Building, UNN, popularly known as GS building; the lecturer was not forthcoming and he decided to preach to the students. After the message, he went and sat down after which one of the students came and requested for his contact number. Later, he had a discussion with the student from where he discovered that the student was a cultist who had been looking for a way out from his evil ways of life.
Ndukaaku concluded that the student is presently the evangelism coordinator of one of the fellowships on campus.

The majority of the informants to this research attested to the fact that in contemporary times, members of various campus fellowships hardly embark on morning cry. Morning cry is a method of evangelism whereby someone or a group of persons publicly preaches the word of God along the streets usually between the hours of 4 am and 6 am with the aid of megaphone or other public address devices. Undoubtedly, this dwindling nature of morning cry is not only peculiar to students' fellowships, but the practice is also very uncommon amongst Christians in recent times. In the past, many students had their personal megaphones which they use almost every morning to carry out morning cry in their hostels or surroundings. However, in recent times, it is regarded as an outdated practice. According to Nzeribe, Olu and Onoja (informants):

'[I]n Abiding Seed Campus Fellowship [ASCF], the evangelism committee prepared rosters for morning cry where members are paired to carry out evangelism in designated hostels. However, the proposal did not yield result because of the constant lack of interest showed by members of the fellowship.'

Only a handful of the members of Abiding Seed Campus Fellowship have consistently showed commitment in embarking on morning cry. The declining interest in morning cry in their respective fellowships is also attested to by Aham, Ifedigbo and Ihim (informants).

\section{Campaign through effectual prayers}

One of the primary activities of various campus fellowships is prayer. The other is the study of the word of God. All the informants such as Abonyi, Enejere and Itodo (informants) emphasised that 'the most powerful instrument that can give a lasting solution to the menace of cultism among students is effectual prayers'. An effectual prayer is a passionate, heartfelt and persistent communication with God for the purposes of worship, intercession or supplication. This definition aligns with the words in the last part of James 5:16: 'The effective, fervent prayer of a righteous man avails much' (New King James Version). In various fellowships, intercessory prayers are made for students, staff and entire university community. According to Amadi, Ibe, Obichukwu and Obochi (informants), 'in the fellowships they belong, apart from the prayers they say on their Sunday gathering, every Thursday is dedicated to prayers in a program known as prayer meeting.' For instance, Anglican Students Fellowship (ASF) holds their prayer meeting known as Prayer Quake every Thursday. For redeemed Christian campus fellowship (RCCF), their prayer meeting is referred to as 'Faith Clinic' and is held on Thursdays. A member of Methodist Campus Fellowship (Ossai, informant) informed the researchers that their general fellowship prayer known as 'Moment of Recovery' takes place every Friday by $5 \mathrm{pm}$. In their prayers meetings, amongst other prayer requests, they call upon God to silence the storms of cultism, robbery, exam malpractice, 
sexual abuse, violence and suicide amongst university students. Apart from the usual prayer meeting which is meant for every member of the fellowship, there is a special prayer warriors group which is particularly meant for intercessors. Ezeja and Ugwuanyi (informants) posited that:

'[T] hey are part of the special prayer warriors group in Watchman Campus Fellowship (WCF) and there is obvious evidence that their prayers are not in vain with regard to the menace of cultism in tertiary institutions.'

Ezeja narrated that during one of their prayer sessions, a student ran into their midst and told them to pray for him because his life was at risk as a result of an ongoing clash between his cult group and another cult group. They preached the message of repentance to him, counselled and also prayed for him; thereafter, he became actively involved in the fellowship.

\section{Campaign through tracts and literature ministry}

Members of various Christian campus fellowships also carry out crusade against cultism and other social ills commonly associated with students through the instruments of tracts and other Christian literature. The major avenue for distributing the tracts and other Christian texts is evangelism. A student evangelist may decide to go along the environment of the university distributing tracts to both staff and students. Tracts are also found very useful in a situation whereby an evangelist meets someone who does not have enough time to listen to what the evangelist has to say. The literature committee of the House on the Rock Campus Fellowship (HRCF) writes and publishes tracts/ pamphlets which they distribute to both members and non-members of the group. They also make use of tracts written by other Christian denominations. Madu and Ukaoha (informants) supported that:

' $[D]$ uring their evangelism programs, they give out tracts to their listeners after preaching the word of God to them. They also give to those who do not have the opportunity to listen because of time constraints.'

They also submitted that they kept tract boxes at strategic places in the university community, most especially at lecture halls. A tract box is a wooden or paper box where tracts are kept for the members of the public. Interestingly, most of the tracts also provide mobile numbers which readers can call for more clarifications or counselling. Whilst some tracts explicitly discuss about the dangers of cultism, others focus on the need to develop godly characters. Undoubtedly, any student who desires to inculcate godly characters in him/ herself does not get associated with cult practices and other related ills.

Some titles of tracts and pamphlets we have distributed, according to Agunwa, Ebi and Oche (informants), are 'Moulding Godly Youths', 'Christian Youths in Times Like These', 'Say "No" to Youthful passions' and 'Dangers of Cultism Among Students'. These informants also add that they make use of Christian texts as well in their crusade against cultism. These texts are basically reserved for those who newly join their fellowship and more so, they focus on promoting godly principles amongst youths and students. They are used as welcome gifts for students who are first timers in their fellowship. Whilst some explicitly discuss the dangers inherent in cultism, others discuss the right values which students should inculcate. Some of the literatures they circulate are titled: Youth Counseling Modules by Briggs, S., Cultism among University Students by Nwankwo, D., The Making of a Godly Youth: Biblical Insights by Dike, S. and Today's Youths, Tomorrow's Leaders by Ndu, G. Oche (informant) noted that all these texts have subtitles which unequivocally centre on the detriments associated with cultism. During oral interview, an ex-cultist noted that he denounced his cult membership after reading the book How to Say No to Negative Pressure written by Justice Okereke. He said that the book changed his life positively and made him turn to godly ways.

\section{Campaign through social media evangelism}

In recent times, it is very difficult to identify a student who is not on one social media platform or another. Jeremiah (2016) averred that:

[Y]oung people today spend an average of eight (8) hours/day using media, and the vast majority of them have access to a television, computer, internet, a video-game console and a cell phone. (p. 16)

There are many positive and negative effects of social media on students, but wise students maximise the positive effects and do away with the negative trends associated with it. Jeremiah (2016) continued that media provides information about education, safe health practices and can foster social connectedness. However, recent studies raise concerns about media's effects on young people such as aggressive behaviour, risky sexual behaviour, substance use and abuse, disordered eating and academic difficulties resulting from misuse of the media.

Members of various Christian campus fellowships carry out evangelism through various social media platforms. Jeremiah (2016) continued that:

[S]ocial network sites have been used to share the gospel to virtually every nation on earth and countless lives have been changed. Facebook, 2go and WhatsApp are good sites to reach out to people and friends with the gospel of Christ. (p. 19)

Achinike, Emmanuel, Ngwu and Ofor (informants) maintained that 'one of the most effective methods of carrying out evangelism among students and youths is through social media because most youths find it appealing, readily available and contemporaneous'. Odo (informant) submitted that 'he usually writes literary piece which he posts on various social media platforms.' In September 2020, one of his posts was titled 'The Academic, Social and Spiritual effects of Cultism' and he received about 170 comments out of which two came from student cultist, who requested for his contact details. During his discussion with the two students, they promised to disassociate themselves from cult 
activities. Presently, the two students carry out sensitisations against cultism in various secondary schools. Odo continued that in October 2020, he posted a literary piece titled 'Say "No" to Cultism, Say "No" to Premarital Sex, Say "No" to Exam Malpractice'. Similarly, Ugwuonye (informant) noted that 'members of the campus fellowship where he belongs to are in a WhatsApp group where posts which promote godly virtues are shared on regular basis'.

\section{Campaign through open air crusades and seminars}

Another significant contribution which Christian campus fellowships have made in the fight against cultism amongst students is through open air crusades. Synonymous to street preaching or public preaching, open air crusade is the act of propagating a religious faith in public places. Unlike the usual fellowship gatherings, it gives an opportunity to attract crowds larger than most buildings can accommodate. Idu and Obinwa (informants) asserted that 'in UNN, open air crusades are often organised by the Joint Christian Body (JCB) once in a session'. Joint Christian Body is a Christian association which embodies various Christian campus fellowships. In UNN, open air crusades are usually held at Freedom Square or Akanu Ibiam Stadium. Various activities are featured in open air crusades such as film shows, drama presentations, question and answer sessions, prayers and word exposition. After open air crusades, students who surrendered their lives to Jesus are followed up by executive members of various fellowships.

Seminars are also common in many Christian campus fellowships. In these fellowships, facilitators (youth counsellors) are invited to present seminars. Unlike sermons, seminars offer participants the opportunity to ask questions on issues which border them. For instance, in Scripture Union Campus Fellowship (SUCF) and Presbyterian Students Fellowship (PSF), seminars are scheduled once in every semester. Some seminar titles in the past are: 'Cultism: A Monster among Students of Tertiary Institutions', 'Principles of Academic Excellence', 'Striking a Balance between Spiritual Life and Academics among Students', 'The Effects of Social Media on the Spiritual Life and Academics of Students' (Agbo and Mba: informants). Ekwunife (2000) repeated that:

$[F]$ requent seminars, retreats and symposia on cultism will help to sensitize and douse cultism in our tertiary institutions. But for these to be effective, as many youths in these places should be involved both in organizing, delivering papers and leading discussion groups. In other words, youth's active participation in these periodic reflections will dispose them to unearth the causes of cultism in campuses and suggest remedies for it. (p. 21)

\section{Recommendations}

The thrust of this article is to investigate the roles of Christian campus fellowships in the campaign to eradicate cultism amongst students of the UNN. Based on the discussions and findings of this work, the following recommendations are proffered:
1. Students of the UNN should be encouraged by their parents and guardians to identify themselves with any Christian campus fellowship in their institutions.

2. School authorities should recognise and promote the roles of various campus fellowships in the fight against cultism amongst students.

3. School authorities should also support various campus fellowships by giving them moral and financial support, especially for their activities which are aimed at eradicating cultism.

4. Various Christian campus fellowships should also co-opt key personalities in the school administration to act as resource persons during some of their activities such as seminars and open air crusades.

5. Various Christian campus fellowships should have patrons and matrons who will oversee the activities of the campus fellowships and also carry out counselling sessions for students who have counselling needs. The patrons and matrons should also carry out counselling sessions for students who denounce their cult membership because students seem to pay more attention to the words of elders than their fellow students.

6. Various Christian campus fellowships should develop new strategies in order to resuscitate morning cry. If well utilised, morning cry is an effective method of evangelism because it is performed in the quietness of the day when most students are still on their beds.

7. Various Christian campus fellowships should also consider erecting bill boards in strategic areas of the university environment. A bill board could be catchily captioned 'Say "NO" to Cultism'.

8. The frequency of open air crusades should be increased to at least twice in a session because it offers students of various religious faiths appealing opportunities to listen to the word of God.

9. An adage quotes that 'the reward for hard work is more work'. Therefore, various Christian campus fellowships should continue in what they are doing and even intensify their efforts in providing a more lasting solution to the problem of cultism amongst students of the UNN.

\section{Conclusion}

The article examines the significant contributions which various Christian campus fellowships have made in the campaign to eradicate cultism amongst students of the UNN. Amongst other things, it established that there are many detriments associated with cult practices and as a result the government and other relevant NGOs have seen the need to create some level of awareness on the menace. However, the article discovers that the attempts of the government and other organisations yielded little result.

Through their teaching, preaching and other ecclesiastical programmes and practices, Christian campus fellowships have contributed significantly to curb the menace of cultism amongst students in the UNN. The data collected by the researchers during personal communication reveal that some cultists have taken a new leaf as a result of the various 
activities of campus fellowships. Therefore, along side the efforts of various governmental and non-governmental establishments to curb this social ill, academic contributions aimed at instructing students to say a decisive ' $\mathrm{No}^{\prime}$ to cultism are apt and of vital importance.

\section{Acknowledgements}

Professor Dirk Human is acknowledged for registering the authors as research associates in the Department of Old Testament and Hebrew Scriptures, Faculty of Theology and Religion, University of Pretoria.

\section{Competing interests}

The authors declare that they have no financial or personal relationships that may have inappropriately influenced them in writing this article.

\section{Authors' contributions}

C.I.U. carried out the investigations and secondary data analysis of this research output. He also provided the appropriate methodology employed in the study. O.G.C. performed the primary data analysis of the study and wrote the original draft. She also carried out the conceptualisation of the main terms used in this work.

\section{Ethical considerations}

Ethical clearance to conduct this study was obtained from the Research Ethics Committee of the Department of Psychology, University of Nigeria, Nsukka. (D.PSY.UNN/ REC/2021-1-000028).

\section{Funding information}

This research received no specific grant from any funding agency in the public, commercial or not-for-profit sectors.

\section{Data availability}

Data sharing is not applicable to this article as no new data were created or analysed in this study.

\section{Disclaimer}

The views and opinions expressed in this article are those of the authors and do not necessarily reflect the official policy or position of any affiliated agency of the authors, and the publisher/s.

\section{References}

Adejoro, B., 1995, Cultism in Nigerian tertiary institutions, Markson Books, Enugu.

Ajayi, I.A., Ekundayo, H.T. \& Osalusi, F.M., 2010, 'Menace of cultism in Nigerian tertiary institutions: The way out', The Anthropologist 12(3), 155-160. https://doi.org/10. 1080/09720073.2010.11891147

Bodunrin, H., 2002, 'Activities of cultism in Nigerian universities', This Day Newspaper, 21 October, pp. 3-5.

Creswell, J.W., 2007, Qualitative inquiry \& research design: Choosing among five approaches, Sage, Thousand Oaks, CA.

Egbochukwu, E.O., 2009, 'Secret cult activities in institutions of higher learning: Lessons from Nigerian situation', Tribals 7(1), 17-25. https://doi.org/10.1080/097 2639X.2009.11886590

Ekwunife, A.N.O., 2000, Cultism and the youth in Nigerian tertiary institutions, AfroOrbis Publishers, Nsukka.

Eneji, T., 1996, 'Death on the loose as secret cults take over campuses', Sunday Tribune Newspaper, 25 February, pp. 19-21.

Enemuo, C.E., 2021, Fellowship groups in our tertiary institutions: A case study in University of Nigeria, Enugu Campus (UNEC), viewed 19 February 2021, from https:// dynaflexvibes.wordpress.com/2014/03/17/fellowship-groups-in-our-tertiaryinstitutions-a-case-study-in-university-of-nigeria-enugu-campus-unec/.

Ibenegbu, G., 2018, What is cultism and its effects, viewed 19 February 2021, from https://www.legit.ng/1088541-what-cultism-effects.html.

Idoko, E.E., 2020, The meaning and activities of secret cults in tertiary institutions, Chukason Press, Ibadan.

Jeremiah, J., 2016, Reality of media in our generation, FEPAM, Nsukka.

Kalu, O.U., 2001, The scourge of the vandals: Nature and control of cults in Nigerian university system, Joen Press, Enugu.

Kadiri, F., 2018, The dangers of cultism in Nigerian universities, College Books, Lagos.

Nwankwo, D., 2020, Cultism among university students, A-Z, Enugu.

Odoziobodo, I., 1991, Welcome to the university, SNAAP Press, Enugu.

Ogunbameru, O.A., 2004, 'Personality dimensions to cultism in Nigerian tertiary institutions: A socio-biological perspective', Journal of Human Ecology 16(2), 91-98. https://doi.org/10.1080/09709274.2004.11905721

Okorie, J.U., 1999, Student affairs, Cape Publishers International, Onitsha.

Okwu, O.J., 2006, 'A critique of students' vices and the effect on quality of graduates of Nigerian tertiary institutions', Journal of Social Sciences 12(3), 193-198. https:// doi.org/10.1080/09718923.2006.11978391

Osondu, B., 2019, Cultism among students: Wider reflections, Marksons Publishers, Onitsha.

Ozoemene, M., 2019, Contemporary issues in Nigerian tertiary institutions, Excellent Books and Publishers, Enugu.

Ufuoma, B.I.C., 2007, Social causes, consequences and remedy of cultism on the campus in Nigeria, African Studies Publishers, Port Harcourt. 


\section{Appendix 1}

TABLE 1: Personal communication (pseudonyms are used for the names of informants).

\begin{tabular}{|c|c|c|}
\hline S/No & Name of informant & Name of fellowship \\
\hline 1 & Abonyi, S. & Nigerian Federation of Evangelical Students \\
\hline 2 & Achinike, E. & Deeper Life Campus Fellowship \\
\hline 3 & Adetunji, D. & Word of Life Student Fellowship \\
\hline 4 & Agbo, M. & Scripture Union Campus Fellowship \\
\hline 5 & Agunwa, E. & Methodist Campus Fellowship \\
\hline 6 & Aham, I. & Baptist Students Association \\
\hline 7 & Amadi, $\mathrm{F}$. & Anglican Students Fellowship \\
\hline 8 & Amaechi, S. & Christ Ambassadors Students Outreach \\
\hline 9 & Asogwa, 0 . & Methodist Campus Fellowship \\
\hline 10 & Ama, $\mathrm{H}$. & Students Christian Movement \\
\hline 11 & Chikwem, L. & Deeper Life Campus Fellowship \\
\hline 12 & Dike, G. & Vineyard Workers Students Fellowship \\
\hline 13 & Diugwu, B. & Believers Love World Fellowship \\
\hline 14 & Ebi, O. & Abiding Word Students Gathering \\
\hline 15 & Ebizie, $\mathrm{T}$. & Nigerian Federation of Catholic Students \\
\hline 16 & Egbuonu, A. & Word of Life Student Fellowship \\
\hline 17 & Emmanuel, $\mathrm{N}$. & Baptist Students Association \\
\hline 18 & Eme, $S$. & Scripture Union Campus Fellowship \\
\hline 19 & Enejere, $\mathrm{M}$. & Nigerian Federation of Evangelical Students \\
\hline 20 & Ezeilo, R. & Christ Ambassadors Students Outreach \\
\hline 21 & Ezeja, E. & Watchman Campus Fellowship \\
\hline 22 & Ezeudu, T. & Abiding Word Students Gathering \\
\hline 23 & Ibe, U. & Anglican Students Fellowship \\
\hline 24 & Idu, E. & Students Christian Movement \\
\hline 25 & Igwe, D. & Christ Ambassadors Students Outreach \\
\hline 26 & Ifedigbo, A. & Baptist Students Association \\
\hline 27 & Ihim, E. & Methodist Campus Fellowship \\
\hline 28 & Itodo, V. & Nigerian Federation of Evangelical Students \\
\hline 29 & Jideofor, B. & Students Christian Movement \\
\hline 30 & Mba, O. & Presbyterian Students Fellowship \\
\hline 31 & Madu, V. & House on the Rock Campus Fellowship \\
\hline 32 & Nduka, U. & Scripture Union Campus Fellowship \\
\hline 33 & Ndukaaku, J. & Abiding Word Students Gathering \\
\hline 34 & Ngwu, 0. & Deeper Life Campus Fellowship \\
\hline 35 & Nnam, N. & Vineyard Workers Students Fellowship \\
\hline 36 & Nzeribe, $\mathrm{H}$. & Abiding Seed Campus Fellowship \\
\hline 37 & Obichukwu, A. & Redeemed Christian Campus Fellowship \\
\hline 38 & Obinwa, N. & Believers Love World Fellowship \\
\hline 39 & Obochi, N. & Redeemed Christian Campus Fellowship \\
\hline 40 & Oche, D. & The Apostolic Campus Fellowship \\
\hline 41 & Odo, $\mathrm{H}$. & Christian Union \\
\hline 42 & Ofor, $F$. & Grace Campus Fellowship \\
\hline 43 & Ogbu, G. & Divine Grace Students Outreach \\
\hline 44 & Olu, A. & Abiding Seed Campus Fellowship \\
\hline 45 & Okolie, A. & Believers Love World Fellowship \\
\hline 46 & Onoja, G. & Abiding Seed Campus Fellowship \\
\hline 47 & Ossai, T. & Methodist Campus Fellowship \\
\hline 48 & Ugo, M. & The Apostolic Campus Fellowship \\
\hline 49 & Ugwuanyi, K. & Watchman Campus Fellowship \\
\hline 50 & Ugwuonye, S. & Christian Union \\
\hline 51 & Ukaoha, I. & House on the Rock Campus Fellowship \\
\hline
\end{tabular}

